\title{
Genetic Relationships between Elite Oil Palms from Nigeria and Selected Breeding and Germplasm Materials from Malaysia via Simple Sequence Repeat (SSR) Markers
}

\author{
M. N. Okoye ${ }^{1,3}$, C. Bakoumé 2 , M. I. Uguru ${ }^{3}$, R. $\operatorname{Singh}^{4} \&$ C. O. Okwuagwu ${ }^{1}$ \\ ${ }^{1}$ Plant Breeding Division, Nigerian Institute for Oil Palm Research (NIFOR), Benin City, Nigeria \\ ${ }^{2}$ Sime Darby Technology Centre, UPM-MTDC Technology Centre III, Serdang, Selangor, Malaysia \\ ${ }^{3}$ Department of Crop Science, Faculty of Agriculture, University of Nigeria, Nsukka, Nigeria \\ ${ }^{4}$ Advanced Biotechnology and Breeding Centre, Malaysian Palm Oil Board (MPOB), Kajang, Selangor, \\ Malaysia \\ Correspondence: M. N. Okoye, Plant Breeding Division, Nigerian Institute for Oil Palm Research (NIFOR), \\ P.M.B. 1030 300001, Benin City, Nigeria. E-mail: maxokoye2001@yahoo.co.uk; maxwellokoye@gmail.com
}

Received: November 19, 2015 Accepted: December 29, 2015 Online Published: January 15, 2016

doi:10.5539/jas.v8n2p159 URL: http://dx.doi.org/10.5539/jas.v8n2p159

\begin{abstract}
Nine SSR markers were used to study the genetic relationships among 26 elite oil palm materials from Nigeria and Malaysia. The Nigerian elite materials comprised 15 Nigerian Institute for Oil Palm Research (NIFOR) oil palm parental genotypes. The 11 Malaysian genotypes included 2 dura and 2 pisifera advanced breeding lines, 3 palms from natural populations of Nigeria, and 2 from each of the Angola, and Madagascar natural oil palm collections maintained at the Malaysian Palm Oil Board (MPOB). The results revealed a high percentage of polymorphic loci $(83.3 \%)$ in the entire materials with average polymorphic information content (PIC) of 0.7325 . Two SSR markers showed relatively high PIC namely sMg00016 and $\mathrm{sMg} 00179$ (0.8018 and 0.8509, respectively). The mean number of alleles varied from 1.333 in Madagascar germplasm material to 4.889 in NIFOR tenera materials (mean $=2.958$ ). The observed heterozygosity varied from 0.167 in Madagascar material to 0.778 in Nigeria germplasm materials (mean $=0.575$ ) and the expected heterozygosity from 0.153 to 0.643 . The various oil palm provenances showed significant genetic differentiation $\left(\mathrm{F}_{\mathrm{ST}}=0.177, \mathrm{P}=0.001\right)$ indicating the existence of a genetic structure among the materials used. UPGMA analysis based on Rogers' dissimilarity coefficient matrix displayed two main clusters, one separating Madagascar accessions from the rest. PCoA showed that the NIFOR breeding parents clustered closely with MPOB's Nigeria and Angola-derived materials suggesting a common origin of mainland genotypes. The high genetic diversity observed among the MPOB's germplasm materials highlights the need for proper characterization of entire NIFOR oil palm germplasm with SSR markers to facilitate effective utilization in the breeding programme.
\end{abstract}

Keywords: Elaeis guineensis Jacq., cluster analysis, genetic diversity, germplasm, microsatellite markers, MPOB, NIFOR, oil palm breeding

\section{Introduction}

The oil palm (Elaeis guineensis Jacq.) is indigenous to Africa and specifically, endemic to the South-Eastern States of Nigeria (Maizura et al., 2006; Bakoumé et al., 2015). The most important products of the crop are palm oil and palm kernel oil. Palm oil is the most valuable natural oil in the diets of Nigerians, both as crude red palm oil and as olein (Corley \& Tinker, 2003). Oil palm produces more than five times oil ha $\mathrm{yr}^{-1}$ of any annual oil crop (Basiron et al., 2005). Presently, Nigeria is the fifth largest producer of palm oil after Indonesia, Malaysia, Thailand and Colombia; and the largest in Africa (Oil World, 2014). According to the recent USDA World Market and Trade Report, Nigeria's palm oil production was projected at $970 \mathrm{mt}$ in 2015/2016 market year (USDA, 2015). This low national output reflects the need for production of new and improved varieties to ensure that productivity growth keeps pace with the increasing domestic demand. USDA's (2015) report further underpins the four year stagnation of Nigeria's palm oil production with the associated consequences to the oil palm industry.

Beyond the expansion of area under cultivation to accommodate the anticipated increase in the domestic demand for palm oil, steady breeding progress has been achieved in the oil palm genetic improvement programme in 
NIFOR. The performance of improved oil palm planting materials under favourable growth conditions is about three to five times the yield of the best semi-wild palm grove (0.5-1.0 mt.ha $\left.{ }^{-1}\right)$ in Nigeria. Annual production level of 3-3.5 tonnes oil per hectare in mature plantations has been obtained (Okwuagwu et al., 2005). There are prospects of further improvement of oil yield by selection considering that the present plant material is the result of only two generations of selection among breeding populations that are of mostly narrow genetic base (Sparnaaij, 1972; Okwuagwu, 1986). Pedigree analysis of some oil palm breeding parents currently used by most oil palm improvement programmes for the production of the hybrid tenera planting materials indicate that they are closely related. Despite the richness of oil palm genetic resources in Nigeria, only a small proportion of the oil palm germplasm collections have been used in breeding programmes. The NIFOR main breeding population consists of dura and tenera selections from the early Aba and Calabar genetic blocks as well as from Ufuma and Angola concentration areas. The descendants of these selections form the backbone of the present main breeding parents and source of some commercial planting materials in Nigeria and Costa Rica (Barbosa \& Chinchilla, 2003). Elsewhere in Malaysia, the elite breeding populations are dominated by Deli dura and AVROS (Algemeene Vereniging van Rubber Planters ter Oostkust van Sumatra) pisifera. The Deli dura palms are descendants of four palms introduced into Bogor Botanical Gardens in the Deli region of Indonesia in 1848 (Jagoe, 1952; Kushairi \& Rajanaidu, 2000; Cochard et al., 2009). Intense breeding and selections on the Bogor descendants over several generations gave rise to the Deli dura population (Kushairi, 2002) currently used for seed production worldwide. In the NIFOR improvement programme, Deli dura from various sources (Malaysia, Jamaica, and Ecuador) were introgressed to form part of the dura sub-population. The narrow genetic base of the Deli dura is not very different with the AVROS pisifera populations which constitute the bulk of pisifera gene pool in South East Asia (Rosenquist, 1986; Rajanaidu et al., 2000; Corley \& Tinker, 2003). The AVROS pisifera are descendants of the Yangambi or D'jongo population which originated from a single plant selected at the Eala Botanical Garden of Yangambi in the Democratic Republic of Congo because of its heritable high oil production. This narrow genetic base of most ancestral populations has been described by Rosenquist $(1986,1992)$ as breeding populations of restricted origin (BPRO), a practice that heightens the risk of decreased genetic diversity in commercial oil palm production. As a consequence, a high genetic similarity is found in the production of several planting materials distributed worldwide. The continued reliance on the exploitation of the limited selection of Deli and African materials will greatly limit future breeding progress. The exploitation of different oil palm breeding populations in the country (Aba, Opobo, Umuabi, Ufuma, Nsukka, Afikpo) and elsewhere will accelerate genetic progress in the development of improved oil palm planting materials. The developments from the 1973 NIFOR/MARDI Nigerian germplasm collection are an affirmation of the possibilities that abound in the Nigerian groves (Rajanaaidu et al., 1992, 1996; Kushairi et al., 1999).

Genetic diversity among individuals or populations can be measured using morphological, biochemical, and molecular techniques (Mohammadi \& Prasanna, 2003). Morphological variables have been routinely employed to evaluate genetic diversity among NIFOR oil palm breeding populations (West, 1976; Ataga, 1988; Okoye, 2008; Okwuagwu et al., 2008). West (1976) evaluated the NIFOR main breeding programme using yield parameters and fruit and bunch quality traits to select parents for the second generation of the breeding programme. New introductions were equally selected on the basis of agronomic traits to broaden the genetic base of breeding populations. Genetic variation of agronomic traits in the NIFOR testcross populations of the second breeding cycle revealed significant variation for the bunch yield traits (Okoye, 2008; Okwuagwu et al., 2008). In a morphological characterization of the 1973's NIFOR/MARDI germplasm accessions, a wide range of genetic variability for vegetative and yield traits (Nigerian Institute for Oil Palm Research, 1988; Rajanaidu et al., 1989) was detected and even led to their classification into eight groups (Ataga, 1988). Progenies with slow height increment were selected for introgression in the breeding programme. Although promising results were obtained, morphological markers are not sufficiently reliable due to low polymorphism, vulnerability to environmental factors and confounding effects of plant developmental stage.

Molecular markers are neutral, not environment dependent, and detectable at all plant growth stage (Mohan et al., 1997). They provide an opportunity to characterize genotypes and to assess plant genetic diversity more precisely than agro-morphological markers (Brumlop \& Finckh, 2011). Among the available molecular markers, microsatellites or simple sequence repeats (SSRs) markers are more faithful in plant genetic diversity study due to their high polymorphism, co-dominant inheritance, reproducibility and abundance throughout the plant genome when compared to restriction fragment length polymorphic DNA (RFLP), random amplified polymorphic DNA (RAPD), and amplified fragment length polymorphism (AFLP) (Powell et al., 1996; Gupta et al., 1999; Philips \& Vasil, 2001; McCouch et al., 2002; Singh \& Cheah, 2005; Feng et al., 2009). The cost and research effort required for development of DNA sequence information are shortcomings of this microsatellite marker technique. However, they are readily transferable (Zane et al., 2002), and easily assayed using polymerase chain reaction (PCR) and 
capillary electrophoresis (Morgante \& Olivieri, 1993; Peakall et al., 1998). Multiplexing PCR products/reactions on single gels also reduces the workload for studies requiring a large number of samples (Saghai Maroof et al., 1994).

SSRs have proven their advantage and suitability in oil palm population genetics studies (Billotte et al., 2001; Singh et al., 2008; Arias et al., 2012; Taeprayoon et al., 2015; Bakoumé et al., 2015), varietal identification (Rajinder et al., 2007; Norziha et al., 2008; Thawaro \& Te-Chato, 2010; Bakoumé et al., 2011; Hama-Ali et al., 2014), pedigree analysis, genome mapping and QTL detection for molecular marker-assisted selection (Billotte et al., 2010; Ting et al., 2013). Considerable amount of molecular markers studies on oil palm have already been conducted by many oil palm research centres in Malaysia (Malaysian Palm Oil Board, MPOB), France (Centre de Coopération en Recherche Agronomique pour le Développemen, CIRAD), Indonesia (Indonesian Oil Palm Research Institute, IOPRI), and Brazil (Empresa Brasileira de Pesquisa Agropecuária, EMBRAPA), to name a few. Unfortunately, not as much research works has emerged from the putative centre of distribution of the species i.e. Nigeria (NIFOR) as well as from the West African oil palm belt. Some of these studies have either evaluated the within species genetic variability, molecular marker-trait association (QTLs) or established species phylogenetic relationships including populations of African origin.

Despite the importance of information on genetic diversity in plant improvement and conservation, no studies, have been specifically conducted on genetic diversity of the current NIFOR oil palm breeding parents with reference to advanced breeding lines available elsewhere (e.g. in MPOB, Malaysia) and African oil palm germplasm materials. Therefore, the objective of this study was to evaluate the genetic variation and the genetic relationships among the NIFOR oil palm breeding parents and selected MPOB's breeding and germplasm materials using simple sequence repeat markers.

\section{Materials and Methods}

\subsection{Plant Material}

A total of 26 E. guineensis palms from eight separate sources i.e. three for NIFOR breeding materials, two of MPOB advanced breeding lines, and three germplasm materials maintained in MPOB's field gene bank at Kluang Johor, Malaysia were used in this study. Details on the origin, number of oil palms sampled by origin, and the fruit type of each oil palm sampled are presented in Table 1. The NIFOR genotypes are parents currently used in the second cycle reciprocal recurrent selection of the oil palm breeding programme. Fresh leaf tissues were collected from leaflets of an unopened spear at the NIFOR Main Station, Benin City, Nigeria. Materials from MPOB consisted of 2 advanced dura and pisifera palms and the oil palm natural accessions collected in Nigeria (3 palms), Angola (2 palms), and Madagascar ( 2 palms). Nigerian oil palms were collected from different eco-climatic zones that support the production of the crop (Obasola et al., 1983). 
Table 1. List of oil palm populations sampled and their origin

\begin{tabular}{|c|c|c|c|}
\hline $\mathrm{S} / \mathrm{n}$ & Code & Pedigree/origin & Fruit form \\
\hline & Deli dura NIFOR breeding population (DDN) & & \\
\hline 1 & DD1 & Serdang Avenue (Malaysia) & Deli dura \\
\hline 2 & DD2 & Serdang Ave. ex IRHO-Pobe & Deli dura \\
\hline 3 & DD3 & Ulu Remis Deli ex Sabah & Deli dura \\
\hline \multirow[t]{2}{*}{4} & DD4 & Ecuador Deli & Deli dura \\
\hline & NIFOR dura breeding population (ND) & & \\
\hline 5 & AD1 & Calabar & dura \\
\hline 6 & AD3 & Ufuma & dura \\
\hline 7 & $\mathrm{AD} 4$ & Opobo & dura \\
\hline \multirow[t]{2}{*}{8} & AD5 & Aba & dura \\
\hline & NIFOR tenera breeding population (NT) & & \\
\hline 9 & $\mathrm{~T} 1$ & Ufuma ex Aba & tenera \\
\hline 10 & $\mathrm{~T} 2$ & Calabar & tenera \\
\hline 11 & $\mathrm{~T} 3$ & Aba ex Calabar & tenera \\
\hline 12 & T5 & Ufuma & tenera \\
\hline 13 & $\mathrm{~T} 6$ & Umuabi OP & tenera \\
\hline 14 & $\mathrm{~T} 7$ & Aba & tenera \\
\hline \multirow[t]{2}{*}{15} & $\mathrm{~T} 8$ & Ufuma ex Aba & tenera \\
\hline & Advanced dura breeding lines from MPOB (MPOB-D) & & \\
\hline 16 & MPOB-D1 & Kluang & dura \\
\hline \multirow[t]{2}{*}{17} & MPOB-D2 & Kluang & dura \\
\hline & Advanced pisifera breeding lines from MPOB (MPOB-P) & & \\
\hline 18 & MPOB-P1 & Kluang & pisifera \\
\hline \multirow[t]{2}{*}{19} & MPOB-P2 & Kluang & pisifera \\
\hline & MPOB's Nigerian germplasm materials (G-NG) & & \\
\hline 20 & G-NG1 & Nigeria & na \\
\hline 21 & G-NG2 & Nigeria & na \\
\hline \multirow[t]{2}{*}{22} & G-NG3 & Nigeria & Fertile pisifera \\
\hline & MPOB's Angola germplasm materials (G-AG) & & \\
\hline 23 & G-AG1 & Angola & na \\
\hline \multirow[t]{2}{*}{24} & G-AG2 & Angola & na \\
\hline & MPOB's Madagascar germplasm materials (G-MG) & & \\
\hline 25 & G-MG1 & Madagascar & na \\
\hline 26 & G-MG2 & Madagascar & na \\
\hline
\end{tabular}

Note. na $=$ not available.

\subsection{Methods}

\subsubsection{Sample Collection}

Each leaf sample was placed in a separate labelled zip lock polyethylene bag in an airtight container with ice chips, and temporarily kept in a cold room at $-80{ }^{\circ} \mathrm{C}$ at the Bioscience Centre of the International Institute of Tropical Agriculture (IITA) Ibadan, until DNA extraction. In addition to the NIFOR provenances, DNA of 11 other palm samples was obtained from MPOB.

\subsubsection{DNA Extraction}

DNA extraction was performed at IITA following a CTAB (hexadecyltrimethylammonium bromide) protocol developed by Doyle and Doyle (1990) with minor revisions. DNA quality assessment and quantification was carried out using Nanodrop ${ }^{\mathbb{R}}$ (ND-1000) spectrophotometer (Thermo Fisher Scientific Inc., Denver). DNA 
samples were stored at $-20{ }^{\circ} \mathrm{C}$ until microsatellite marker analysis at the Genomics Unit of Advanced Biotechnology and Breeding Centre (ABBC), Malaysian Palm Oil Board (MPOB) Selangor, Malaysia. The stock DNA samples were diluted to a working concentration of $25 \mathrm{ng} / \mu \mathrm{l}$ by addition of sterile distilled water or appropriate amount of TE (Tris-EDTA) buffer and stored at $4{ }^{\circ} \mathrm{C}$ until PCR amplification.

\subsubsection{SSR Analysis}

Sixteen microsatellite loci comprising nine markers developed at MPOB (Low et al., 2008; Singh et al., 2008) and seven at CIRAD (Billotte et al., 2005) were tested on a subset of DNA samples. Genomic DNA of 26 individuals corresponding to the eight provenances was analyzed using the SSR loci as described by Ting et al. (2010). Amplification was performed with a Perkin Elmer 9700 thermocycler (Life Technologies, Thermo-Fisher Scientific, USA) in a final reaction volume of $10 \mu$ l containing: $2 \mu 1$ of $25 \mathrm{ng}$ genomic DNA, $6.625 \mu 1 \mathrm{MilliQ}$ water, $1 \times$ PCR standard buffer (NEB, USA), $0.2 \mu 1$ of $10 \mathrm{mM}$ deoxynucleotide triphosphates (dNTPs) (NEB, USA), $0.025 \mu \mathrm{l}$ of each of M13-tailed forward primer and untailed reverse primer, $0.025 \mu 1$ dye, and $0.1 \mu 1$ of Taq DNA polymerase (5 U/ $\mu$ l) (NEB, USA). Amplification reactions were multiplexed based on the annealing temperature of the corresponding primer pairs. In the multiplex PCRs, each of the four forward primers was labelled at the 5'end with one of the 6-FAM, NED, VIC and PET fluorescent dyes. The PCR amplification cycle consisted of an initial $3 \mathrm{~min}$ denaturing at $95{ }^{\circ} \mathrm{C}$, followed by 35 cycles of denaturation at $95^{\circ} \mathrm{C}$ for $30 \mathrm{sec}$, primer annealing for $30 \mathrm{sec}$ at $50-58{ }^{\circ} \mathrm{C}$ depending on the primer annealing temperature indicated in Table 2 , an extension at $72{ }^{\circ} \mathrm{C}$ for $30 \mathrm{sec}$, followed by a final extension at $72{ }^{\circ} \mathrm{C}$ for $2 \mathrm{~min}$. PCR products were preliminary checked for the presence of amplicons on a $0.9 \%$ of SFR agarose gel run in $1 \times \mathrm{TAE}$ buffer for 45 minutes, stained with ethidium bromide, and visualized by UV light (Figure 1). The PCR products were separated and analyzed on ABI 3730 DNA Genetic Analyzer (Applied Biosystems, USA; Figure 2). The size of the amplified products was calculated based on an internal standard- GS 500 LIZ size standard- (Applied Biosystems, USA) with GeneMapper ${ }^{\circledR}$ Software v 4.1 (Applied Biosystems, USA).

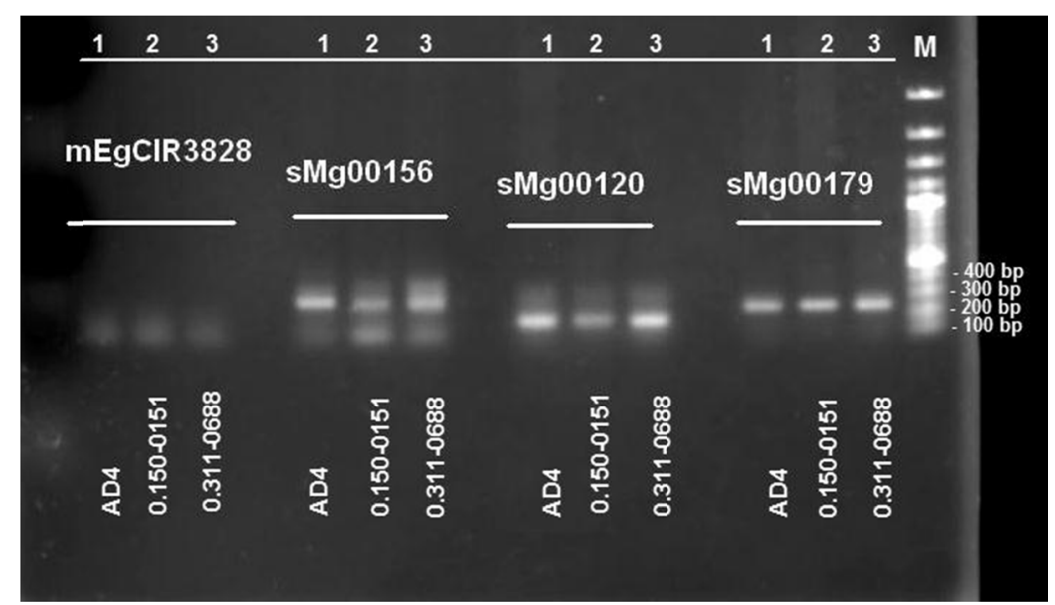

Figure 1. Microsatellite profile of some oil palm genotypes generated by 4 of 16 markers (mEgCIR3828, $\mathrm{sMg} 00156, \mathrm{sMg} 00120$, and $\mathrm{sMg} 00179$ )

Note. $\mathrm{M}=100$ base pair ladder; AD4 = NIFOR dura; $0.150-0151=$ Nigeria accession; $0.311-0688=$ Angola accession. 

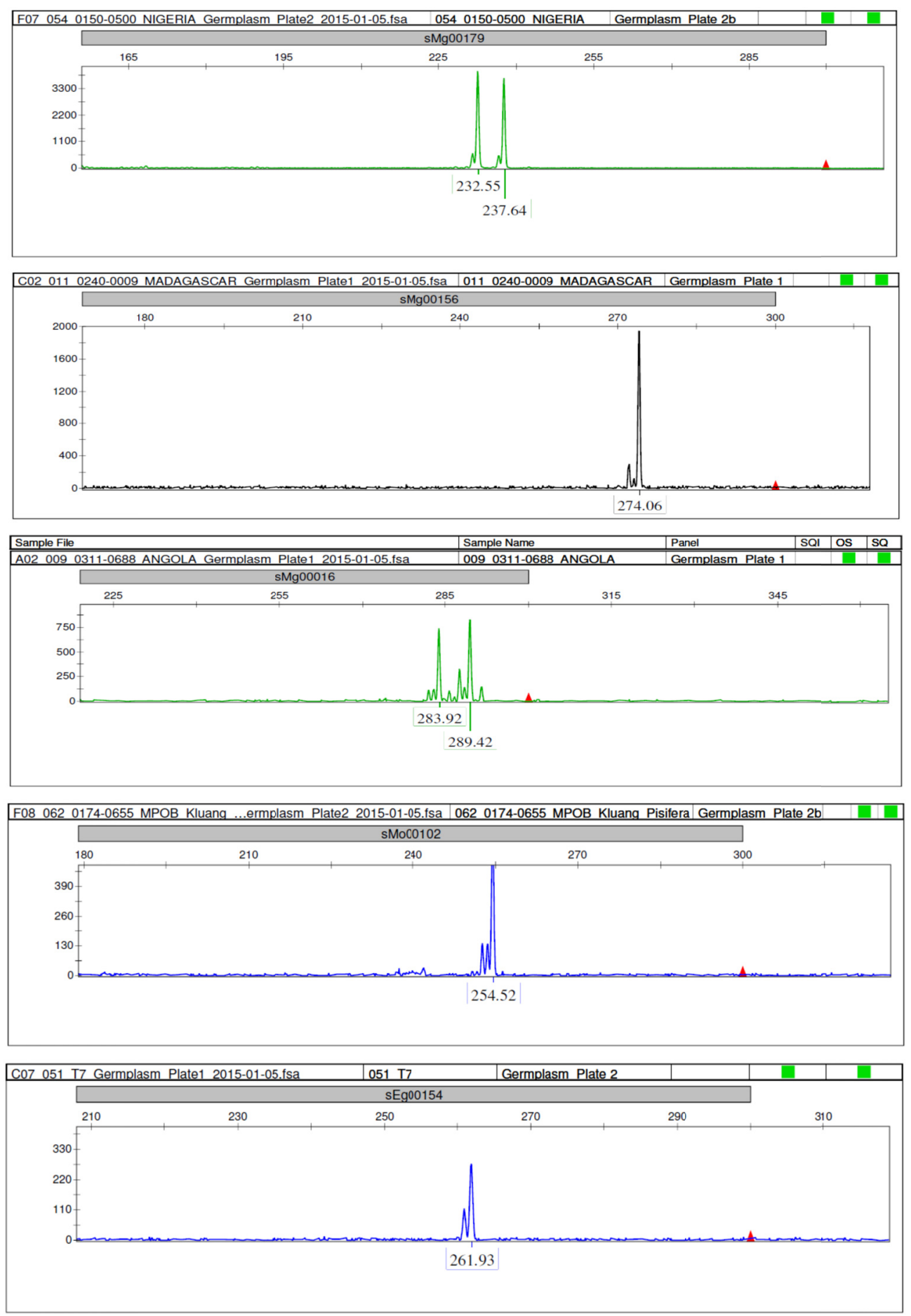

Figure 2. Electropherogram profile showing the separation of some oil palm genotypes on ABI 3730 DNA Genetic Analyzer using markers sMg00179, sMg00156, sMg00016, sMo00102, and sEg00154 
Table 2. Microsatellite primer pairs used for population genetic analysis of oil palm

\begin{tabular}{|c|c|c|c|c|c|c|c|c|}
\hline $\mathrm{S} / \mathrm{N}$ & SSR loci & $\begin{array}{l}\text { Linkage } \\
\text { group }\end{array}$ & $\begin{array}{l}\mathrm{Ta} \\
\left({ }^{\circ} \mathrm{C}\right)\end{array}$ & Primer sequence & SSR repeat motif & $\begin{array}{l}\text { Expected } \\
\text { fragment } \\
\text { size (bp) }\end{array}$ & $\begin{array}{l}\text { Fluorescent } \\
\text { label }\end{array}$ & $\begin{array}{l}\text { Accession } \\
\text { number }\end{array}$ \\
\hline \multirow[t]{2}{*}{1} & $\mathrm{mEgCIR} 3813$ & 1 & 52 & F-CATACCCTGCTTATCTTTC & $(\mathrm{GA}) 19$ & 167 & FAM & AJ578734 \\
\hline & & & & R-GTAGATACCCGTTAGTTGAC & & & & \\
\hline \multirow[t]{2}{*}{2} & mEgCIR0793 & 2 & 56 & F-GTACTTCGCAACTATTCCTTTTCTT & (GA) 15 & 149 & FAM & AJ578545 \\
\hline & & & & R-AGTTGATCGTGGTGCCTGAC & & & & \\
\hline \multirow[t]{2}{*}{3} & mEgCIR0425 & 3 & 58 & F-AGCAAGAGCAAGAGCAGAACT & $(\mathrm{CCG}) 9$ & 232 & NED & AJ578521 \\
\hline & & & & R-CTTGGGGGCTTCGCTATC & & & & \\
\hline \multirow[t]{2}{*}{4} & sMg00156 & 4 & 50 & F-GGTGTCATAACTTCGTTGTTGCT & (CT) 15 & 237 & NED & $\operatorname{Pr} 010615888^{*}$ \\
\hline & & & & R-ATGCTCAAAAGTGGGTTTCTCTC & & & & \\
\hline \multirow[t]{2}{*}{5} & mEgCIR3828 & 5 & 50 & F-AGCCAGATGGAAATACAC & $(\mathrm{GA}) 23$ & 282 & VIC & AJ578738 \\
\hline & & & & R-GTGCGATAAAGAGGAGAGT & & & & \\
\hline \multirow[t]{2}{*}{6} & sEg00154 & 6 & 57 & F-TCCCCCAATACTCATCATGC & $(\mathrm{CAG}) 5$ & 238 & FAM & EY410356** \\
\hline & & & & R-TGATCGACGGTTGTCACATT & & & & \\
\hline \multirow[t]{2}{*}{7} & sMo00102 & 7 & 53 & F-ATGAGATGGGACAAATCAAAC & $(\mathrm{AG}) 11$ & 235 & FAM & Pr010615939* \\
\hline & & & & R-ACCATACCAACTAGAGAACTAAACA & & & & \\
\hline \multirow[t]{2}{*}{8} & sMg00228 & 8 & 54 & F-CACGTATATGAGCAGGATTTGA & (AT) 25 & 205 & PET & Pr010615913* \\
\hline & & & & R-CTCCAAACCAACTAGAGCTGA & & & & \\
\hline \multirow[t]{2}{*}{9} & sMg00016 & 9 & 52 & F-GCGATTCCGGTTATCTTTAG & $(\mathrm{GA}) 13$ & 274 & VIC & $\operatorname{Pr} 010615861^{*}$ \\
\hline & & & & R-GAGTTTTTGCTGTGATGATTAG & & & & \\
\hline \multirow[t]{2}{*}{10} & mEgCIR3519 & 10 & 52 & F-CCACTGCTTCAAATTTACTAG & (GA) $15(\mathrm{GT}) 8$ & 236 & NED & AJ578672 \\
\hline & & & & R-GCGTCCAAAACATAAATCAC & & & & \\
\hline \multirow[t]{2}{*}{11} & sMg00120 & 11 & 54 & F-GATCAATGCGAGAAATCAGG & $(\mathrm{AT}) 11$ & 152 & NED & $\operatorname{Pr} 010615881^{*}$ \\
\hline & & & & R-GATCATGCTTATCCTTTCCAAGT & & & & \\
\hline \multirow[t]{2}{*}{12} & mEgCIR0790 & 12 & 52 & F-TTGGTGGTCCTTTTGAATATC & $(\mathrm{GA}) 19$ & 215 & VIC & AJ578544 \\
\hline & & & & R-ACAAACCCAGCACTTAAAATAAC & & & & \\
\hline \multirow[t]{2}{*}{13} & sEg00151 & 13 & 57 & F-ATCACAACAGCAGCAGCATC & $(\mathrm{CAG}) 8$ & 219 & PET & EY411661** \\
\hline & & & & R-CGCATCAAGAAACATGGAGA & & & & \\
\hline \multirow[t]{2}{*}{14} & sMg00179 & 14 & 54 & F-AACCCCTTTTTCATGCTCTAA & $($ AAAA G)6 & 214 & VIC & Pr010615893* \\
\hline & & & & R-CTGATTTTGGAATCAGAGGTG & & & & \\
\hline \multirow[t]{2}{*}{15} & sMg00087 & 15 & 58 & F-CACCTAAAAACGGCAAGGAAC & (AG)19AA(AG) & 212 & PET & $\operatorname{Pr} 010615880^{*}$ \\
\hline & & & & R-GGAGGAGAGAAATGGAAGACG & & & & \\
\hline \multirow[t]{2}{*}{16} & $\mathrm{mEgCIR} 3745$ & 16 & 52 & F-GGAAGTCTTGATGTTGAAAG & (GA)18 & & PET & AJ578718 \\
\hline & & & & R-ATCAAGCAGTCGCATAATAC & & & & \\
\hline
\end{tabular}

Note. $\mathrm{Ta}=$ Annealing temperature; $*$ Probe Unique Identifiers (PUIDs) of NCBI Probe Database; **Accession numbers of NCBI GenBank.

\subsection{Data Analysis}

\subsubsection{Genetic Diversity}

To evaluate the genetic diversity within the oil palm samples, the genetic diversity parameters calculated included percentage of polymorphic loci $(\mathrm{P} \%)$, allelic frequency $\left(\mathrm{F}_{\mathrm{x}}\right)$, mean number of alleles per locus $\left(\mathrm{A}_{\mathrm{o}}\right)$, effective number of alleles per locus $\left(A_{e}\right)$, observed heterozygosity $\left(H_{0}\right)$, and expected heterozygosity $\left(H_{e}\right)$ for each locus and population. The polymorphism information content (PIC) was calculated to assess the discriminating power of the SSR markers used. PIC was calculated for each marker as described by Botstein et al. (1980) and Anderson et al. (1993);

$$
P I C=1-\sum_{i=1}^{n} f_{i}^{2}-\sum_{i-1}^{n-1} \sum_{j=i+1}^{n} 2 f_{i}^{2} f_{j}^{2}
$$


where, $n$ is the number of alleles; and $f_{i}$ and $f_{j}$ are the frequencies of the $i^{\text {th }}$ and $j^{\text {th }}$ alleles, respectively. The proportion of polymorphic alleles $(\mathrm{P})$ is and expressed in percentage and was derived as:

$$
P=\frac{n_{p j}}{n_{\text {total }}} \times 100
$$

where, $n_{p j}$ is the number of polymorphic loci and $n_{\text {total }}$ is the number of loci used. Allele frequency $\left(\mathrm{F}_{\mathrm{x}}\right)$ for co-dominant markers like SSR marker and diploid species like oil palm is defined by the following formula:

$$
F_{x}=\frac{2 N_{x x}+N_{x y}}{2 N}
$$

where, $N_{x x}$ is the number of $x x$ homozygous individuals, $N_{x y}$ is the number of heterozygous individuals and $y$ can be any other allele. $N$ is the number of samples and can be determined by direct count of the proportion of different alleles. Following the approach of Marshall and Brown (1975), comparison of the distribution of common alleles (alleles at frequency $p \geq 0.05$ ) and rare alleles (alleles at frequency $p<0.05$ ) was performed. Effective number of alleles per locus $\left(A_{e}\right)$ is the reciprocal or inverse of homozygosity (Hartl \& Clark, 1989). Therefore as $A_{e}$ gets larger, more individuals become heterozygous. It was calculated as in Crow and Kimura (1970):

$$
A_{e}=1 / \sum(p i)^{2}
$$

where, $p$ is the frequency of the $i^{\text {th }}$ allele at a locus. Observed heterozygosity $\left(\mathrm{H}_{\mathrm{o}}\right)$ was calculated by dividing the number of heterozygous individuals by the number of individuals scored. Expected heterozygosity $\left(\mathrm{H}_{\mathrm{e}}\right)$, is the probability that two alleles from the same locus would be different when chosen at random, and was calculated for each SSR locus according to Nei (1972):

$$
\mathrm{H}_{e}=1-\sum(p i)^{2}
$$

where, $p$ is the frequency of the $i^{\text {th }}$ allele for the population and $\Sigma(p i)^{2}$ is the sum of squared population allele frequencies.

\subsubsection{Genetic Differentiation and Relatedness}

Analysis of molecular variance (AMOVA) was carried out to assess the overall distribution of diversity among and within the provenances while $\mathrm{F}_{\mathrm{ST}}$ (Wright's fixation index) was used to indicate gene differentiation between provenances. All of the calculations were performed using PowerMarker software version 3.25 (Liu \& Muse, 2005), and GenAlEx version 6.5 software (Peakall \& Smouse, 2006, 2012). The genetic relatedness among provenances was estimated by Rogers' (1972) genetic distances calculated for all pairwise comparisons of genotypes as follows,

$$
D_{R}=\frac{1}{m} \sum_{j}^{m} \sqrt{\frac{1}{2} \sum_{i}^{a_{j}}\left(p_{i j}-q_{i j}\right)^{2}}
$$

where, $p_{i j}$ and $q_{i j}$ are the frequencies of $i^{\text {th }}$ allele at the $j^{\text {th }}$ alleles in populations $X$ and $Y$, respectively, $a_{j}$ the number of alleles at the $j^{\text {th }}$ locus, and $m$ the number of loci examined.

A dendrogram was constructed on the basis of the distance matrix using the Unweighted Pair Group Method with Arithmetic mean (UPGMA) described by Sneath and Sokal (1973). The construction of dendogram was performed using the programme MEGA 4.0 (Tamura et al., 2007) embedded in PowerMarker software version 3.25 (Liu \& Muse, 2005). Principal coordinates analysis (PCoA) was carried out using GenAlEx version 6.5 software to further understand the genetic relatedness among oil palm provenances (Peakall \& Smouse, 2006, 2012).

\section{Results}

\subsection{Genetic Diversity in the Oil Palm Materials Studied}

Nine of the 16 primer combinations showed reproducible amplicons as well as variability among the 26 oil palm genotypes analysed. Details on genetic diversity parameters at each locus are presented in Table 3 . A total of 80 alleles were detected among the oil palm sources and the number of alleles per locus ranged from 7 at $\mathrm{sEg} 00151$ to 11 at sMg00156 with an average of 8.9 alleles per locus. Allele frequencies were low, predominantly for loci with higher number of alleles. Only $33 \%$ of the alleles had a frequency equal to or higher than 0.4000 . The most common allele or major allele frequency (MAF) was observed at SSR marker mEgCIR0793 (0.5385) and alleles at lower frequencies at SSR marker $\mathrm{SMg} 00179(\mathrm{MAF}=0.2000)$. The lowest PIC value was recorded for locus $\mathrm{mEgCIR} 0793$ and the highest for $\mathrm{sMg} 00179$. The PIC per marker ranged from 0.6472 to 0.8509 with an average 
value of 0.7325 . The genetic variation measures for each of the nine SSRs across all the various oil palm sources are summarized in Table 3. The mean observed heterozygosity $\left(\mathrm{H}_{0}\right)$ recorded in the various sources of oil palm per locus was 0.6296 , varying from 0.4783 for SSR marker mEgCIR3519 to 0.8077 for SSR marker mEgCIR0793. Expected heterozygosity $\left(\mathrm{H}_{\mathrm{e}}\right)$ ranged from 0.6709 for mEgCIR0793 to 0.8656 for sMg00179. The mean fixation index $(\mathrm{F})$ value was positive $(\mathrm{F}=0.1934)$.

Table 3. Genetic diversity parameters estimated in NIFOR and MPOB oil palm materials using nine SSR markers

\begin{tabular}{|c|c|c|c|c|c|c|c|c|c|c|c|c|c|}
\hline $\mathrm{S} / \mathrm{N}$ & SSR loci & $\begin{array}{l}\text { Linkage } \\
\text { group }\end{array}$ & $\begin{array}{l}\mathrm{Ta} \\
\left({ }^{\circ} \mathrm{C}\right)\end{array}$ & $\begin{array}{l}\text { SSR } \\
\text { repeat } \\
\text { motif }\end{array}$ & $\begin{array}{l}\text { Expected } \\
\text { fragment } \\
\text { size (bp) }\end{array}$ & $\begin{array}{l}\text { Fluoresce } \\
\text { nt dye }\end{array}$ & MAF & G & $\mathrm{A}_{0}$ & $\mathrm{H}_{\mathrm{o}}$ & $\mathrm{H}_{\mathrm{e}}$ & $\mathrm{PIC}$ & $\mathrm{F}$ \\
\hline 1 & mEgCIR0793 & 2 & 56 & $(\mathrm{GA}) 15$ & 149 & FAM & 0.3654 & 16 & 9 & 0.6154 & 0.7766 & 0.7487 & 0.2263 \\
\hline 2 & sMg00156 & 4 & 50 & (CT) 15 & 237 & NED & 0.5385 & 10 & 9 & 0.8077 & 0.6709 & 0.6472 & -0.1851 \\
\hline 3 & sEg00154 & 6 & 57 & $(\mathrm{CAG}) 5$ & 238 & FAM & 0.4783 & 10 & 8 & 0.4783 & 0.6900 & 0.6493 & 0.3268 \\
\hline 4 & sMo00102 & 7 & 53 & (AG)11 & 235 & FAM & 0.3542 & 14 & 11 & 0.5417 & 0.7795 & 0.7510 & 0.3243 \\
\hline 5 & sMg00016 & 9 & 52 & $(\mathrm{GA}) 13$ & 274 & VIC & 0.3043 & 13 & 10 & 0.7826 & 0.8223 & 0.8019 & 0.0704 \\
\hline 6 & mEgCIR3519 & 10 & 52 & $\begin{array}{l}\text { (GA)15 } \\
(\mathrm{GT}) 8\end{array}$ & 236 & NED & 0.2000 & 14 & 9 & 0.6400 & 0.8656 & 0.8509 & 0.2795 \\
\hline 7 & mEgCIR0790 & 12 & 52 & $(\mathrm{GA}) 19$ & 215 & VIC & 0.4200 & 10 & 9 & 0.5600 & 0.7368 & 0.7033 & 0.2591 \\
\hline 8 & sEg00151 & 13 & 57 & $(\mathrm{CAG}) 8$ & 219 & PET & 0.3654 & 12 & 7 & 0.6154 & 0.7404 & 0.6986 & 0.1878 \\
\hline 9 & sMg00179 & 14 & 54 & $\begin{array}{l}\text { (AAAA } \\
\text { G) } 6\end{array}$ & 214 & VIC & 0.3542 & 12 & 8 & 0.6250 & 0.7726 & 0.7413 & 0.2114 \\
\hline & Mean & & & & & & 0.3756 & 12.3333 & 8.8889 & 0.6296 & 0.7616 & 0.7325 & 0.1934 \\
\hline
\end{tabular}

Note. $\mathrm{Ta}=$ Annealing temperature; $\mathrm{MAF}=$ Major allele frequency; $\mathrm{G}=$ Genotype number; $\mathrm{A}_{\mathrm{o}}=$ mean number of alleles; $\mathrm{H}_{\mathrm{o}}=$ Observed heterozygosity; $\mathrm{H}_{\mathrm{e}}=$ Expected heterozygosity/gene diversity; PIC = Polymorphism information content; $\mathrm{F}=$ Fixation index (inbreeding-like effects within the entire population).

\subsection{Genetic Diversity within Oil Palm Samples from Different Sources}

In order to quantify the genetic diversity within and between the different sources of samples analysed, the 26 oil palm genotypes were grouped as shown in Table 1. A total of 8 groups were obtained on the basis of their sources or provenances. The values of the various genetic diversity indices in each of the eight groups are presented in Table 4.

The mean number of alleles per locus per group ranged from 1.889 in the MPOB advanced pisifera lines (MPOB-P) to 4.889 in the NIFOR tenera parents (NT) while the number of effective alleles per locus varied from 1.289 in the Madagascar-derived materials (G-MG) to 3.318 in NT. Major allele frequency (MAF) depended on the SSR marker and on the group as well. Mean MAF ranged from 0.486 in DDN to 0.861 in G-MG (mean $=0.586$ ) for all the SSR markers tested (Table 4). Average number of private alleles (allele found in a single population) among the different groups ranged from 0 in MPOB-D to 8 in G-NG (Table 4). The number of private alleles in the NIFOR provenances varied from 1 in DDN to 6 in NT. The mean percentage of polymorphic loci $(\mathrm{P})$ was $83.33 \%$. It was maximum $(100 \%)$ in the majority of the grouping except for the oil palms from Madagascar (33.33\%), MPOB dura (55.56\%), and MPOB pisifera (77.78\%). Observed heterozygosity $\left(\mathrm{H}_{\mathrm{o}}\right)$ per group ranged from 0.167 in G-MG to 0.778 in G-NG (mean $\left.=0.575\right)$ while expected heterozygosity $\left(\mathrm{H}_{\mathrm{e}}\right)$ varied from 0.153 in G-MG to 0.642 in $\mathrm{G}-\mathrm{NG}(\mathrm{mean}=0.488)$. 
Table 4. Estimates of genetic variability parameters for in each of the NIFOR and MPOB germplasm and breeding materials

\begin{tabular}{lllllllll}
\hline Provenances & $\mathrm{N}$ & $\mathrm{MAF}$ & $\mathrm{A}_{\mathrm{o}}$ & $\mathrm{A}_{\mathrm{e}}$ & $\mathrm{A}_{\mathrm{pr}}$ & $\mathrm{H}_{\mathrm{o}}$ & $\mathrm{H}_{\mathrm{e}}$ & $\mathrm{P}(\%)$ \\
\hline Deli dura NIFOR (DDN) & 4 & 0.486 & 3.333 & 2.720 & 1 & 0.667 & 0.618 & 100 \\
NIFOR dura (ND) & 4 & 0.505 & 3.778 & 3.184 & 5 & 0.750 & 0.600 & 100 \\
NIFOR tenera (NT) & 7 & 0.492 & 4.889 & 3.318 & 6 & 0.683 & 0.638 & 100 \\
Nigeria (G-NG) & 3 & 0.481 & 3.667 & 3.092 & 8 & 0.778 & 0.642 & 100 \\
Angola (G-AG) & 2 & 0.583 & 2.667 & 2.311 & 2 & 0.667 & 0.542 & 100 \\
Madagascar (G-MG) & 2 & 0.861 & 1.333 & 1.289 & 7 & 0.167 & 0.153 & 33.33 \\
MPOB Deli (MPOB-D) & 2 & 0.639 & 2.111 & 1.926 & 0 & 0.333 & 0.347 & 55.56 \\
MPOB pisifera (MPOB-P) & 2 & 0.639 & 1.889 & 1.719 & 3 & 0.556 & 0.361 & 77.78 \\
Mean & & 0.586 & 2.958 & 2.445 & & 0.575 & 0.488 & 83.33 \\
\hline
\end{tabular}

Note. $\mathrm{N}=$ Number of samples; MAF $=$ Major allele frequency; $\mathrm{A}_{\mathrm{o}}=$ Mean number of alleles; $\mathrm{A}_{\mathrm{e}}=$ Effective number of alleles; $A_{p r}=$ Number of private alleles; $H_{o}=$ Observed heterozygosity; $H_{e}=$ Expected heterozygosity/gene diversity; $\mathrm{P}=$ Percentage of polymorphic loci.

\subsection{Genetic Differentiation and Genetic Relatedness among NIFOR and MPOB Breeding and Germplasm Materials}

The analysis of molecular variance (AMOVA) indicated that $82 \%$ of the molecular variation in the 26 oil palm genotypes exists within groups and 18\% among groups (Table 5). Permutation tests (based on 999 permutations) suggest that the overall $\mathrm{F}_{\mathrm{ST}}$ was significant $\left(\mathrm{F}_{\mathrm{ST}}=0.177, \mathrm{P}=0.001\right)$.

Table 5. Analysis of molecular variance for the 26 oil palm genotypes sampled from eight provenances

\begin{tabular}{lllllll}
\hline Source of variation & $\begin{array}{l}\text { Degree of } \\
\text { freedom }\end{array}$ & $\begin{array}{l}\text { Sum of } \\
\text { squares }\end{array}$ & $\begin{array}{l}\text { Mean } \\
\text { square }\end{array}$ & $\begin{array}{l}\text { Estimated } \\
\text { variance }\end{array}$ & $\begin{array}{l}\text { Percentage of } \\
\text { variation (\%) }\end{array}$ & P-value \\
\hline Among provenances & 7 & 49.568 & 7.081 & 0.649 & $18 \%$ & 0.001 \\
Within provenances & 44 & 132.798 & 3.018 & 3.018 & $82 \%$ & 0.001 \\
Total & 51 & 182.365 & & 3.664 & $100 \%$ & 0.001 \\
\hline $\mathrm{F}_{\mathrm{ST}}=0.177$ & & & & & 0.001 \\
\hline
\end{tabular}

Note. $\mathrm{P}=$ probability of the variance components do not explain the total existing variation; $\mathrm{F}_{\mathrm{ST}}=$ amount of inbreeding-like effects within sub-populations.

Pair-wise genetic distance coefficients $\left(D_{R}\right)$ among the 26 different oil palm sources were calculated according to Rogers' (1972). It ranged from 0.1875 between genotypes G-MG1 and G-MG2, G-MG2 and T7 to 0.9208 between G-MG2 and MPOB-D1with an average of 0.6150 (Table 6). With respect to the oil palm natural populations maintained at MPOB, the maximum genetic distance of 0.8117 was obtained for G-AG2 and G-MG1. In the NIFOR parental provenances, $\mathrm{D}_{\mathrm{R}}$ varied from 0.300 between AD5 and AD4 to 0.7059 between $\mathrm{T} 8$ and $\mathrm{AD} 3$ (mean $=0.5346$ ), while in the MPOB advanced planting materials, it ranged from 0.3380 between genotypes MPOB-P1 and MPOB-P2 to 0.7666 between MPOB-D1 and MPOB-P1 (mean $=0.5209$ ).

Cluster analysis was performed to better view genetic relationships among the 26 different genotypes representing the 8 different sources. The dendrogram showed two main clusters, one assembling Madagascar-derived materials and the other one, the biggest, grouping the rest of the samples. The biggest cluster was separated into four sub-clusters (Figure 3). Sub-clusters 2a contained the two MPOB advanced pisifera lines (MPOB-P1 and MPOB-P2). The Angola-derived material (G-AG1) was grouped with MPOB advanced dura line (MPOB-D1) in sub-cluster 2b. All the Nigeria-derived germplasm materials (G-NG1, G-NG 2, and G-NG3) and one Angola-derived germplasm material (G-AG2) maintained at MPOB were grouped with some NIFOR parents (T7, $\mathrm{AD} 5, \mathrm{AD} 4$, and T8) in the same sub-cluster $2 \mathrm{c}$. The 11 remaining NIFOR oil palm parents were grouped in sub-cluster $2 \mathrm{~d}$. 
Table 6. Rogers' (1972) pair-wise genetic distance between 26 oil palm genotypes calculated from SSR analysis data

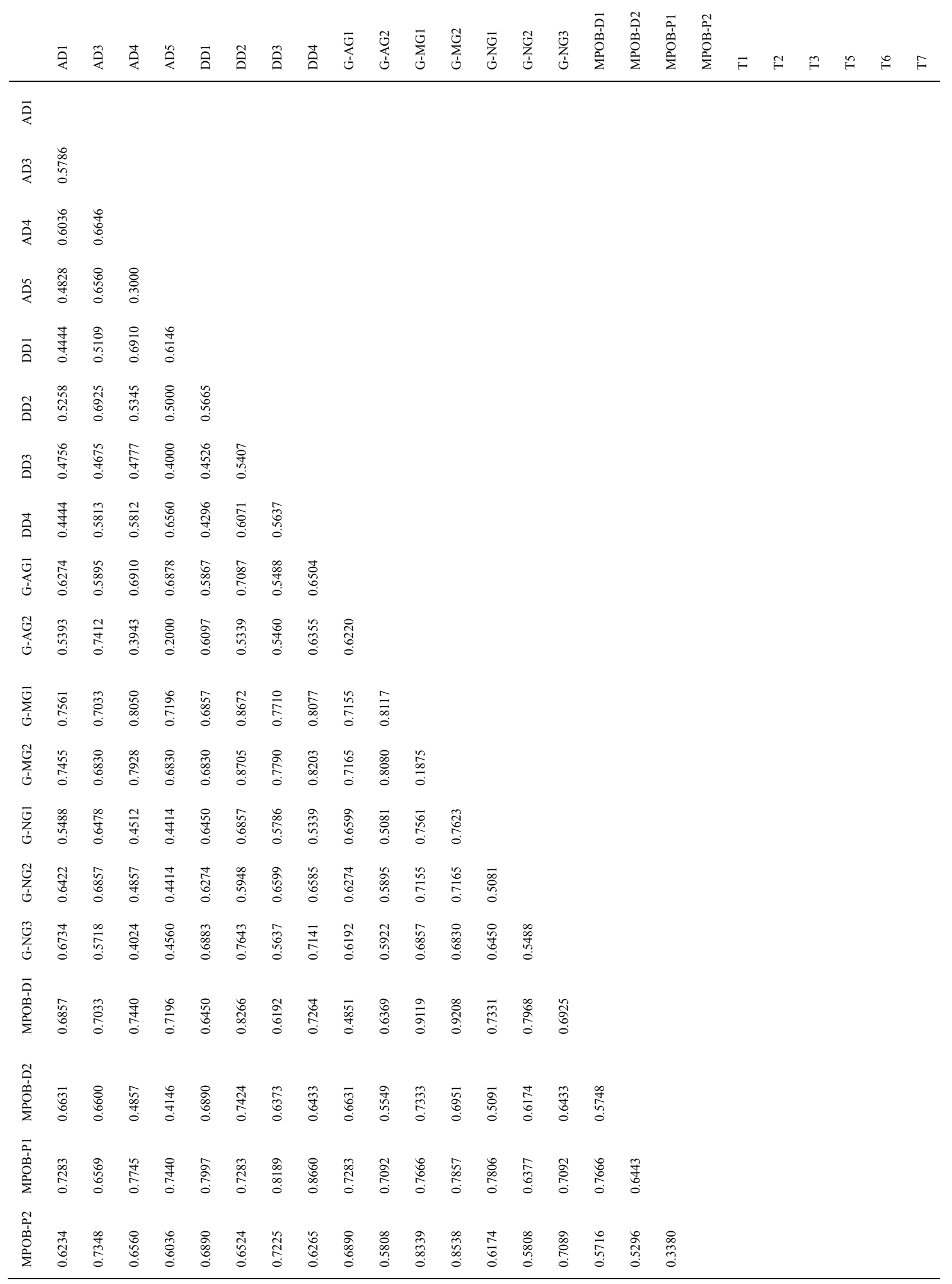




\begin{tabular}{|c|c|c|c|c|c|c|c|c|c|c|c|c|c|c|c|c|c|c|c|c|c|c|c|}
\hline $\begin{array}{l}\hat{\hat{o}} \\
\stackrel{0}{0} \\
0\end{array}$ & 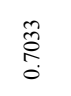 & $\frac{\pi}{3}$ & $\begin{array}{l}\tilde{n} \\
\hat{n} \\
0\end{array}$ & $\begin{array}{l}\text { d. } \\
\text { ôd } \\
\text { d. }\end{array}$ & 各 & $\begin{array}{l}\hat{6} \\
\text { n. } \\
0\end{array}$ & $\frac{b}{b}$ & $\begin{array}{l}\text { ôे } \\
\text { 尺े } \\
\dot{0}\end{array}$ & $\begin{array}{l}\text { S. } \\
\text { oे } \\
0\end{array}$ & 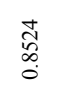 & $\begin{array}{l}0 \\
0 \\
0 \\
0 \\
0 \\
0\end{array}$ & $\begin{array}{l}\text { 总 } \\
\vdots \\
\vdots \\
0\end{array}$ & $\begin{array}{l}\text { ठ̀̃ } \\
\text { bे }\end{array}$ & $\stackrel{c}{\stackrel{c}{c}}$ & 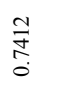 & 莨 & $\begin{array}{l}\text { ô } \\
\text { ลे } \\
0\end{array}$ & م. & & & & & \\
\hline 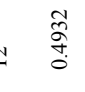 & $\begin{array}{l}\vec{o} \\
\stackrel{0}{0} \\
0\end{array}$ & $\begin{array}{l}8 \\
0 \\
0 \\
0 \\
0\end{array}$ & 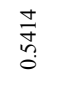 & \begin{tabular}{l}
\multicolumn{2}{c}{} \\
$\stackrel{0}{0}$ \\
0
\end{tabular} & 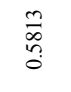 & $\begin{array}{l}\text { ఫे } \\
\text { ఫิ }\end{array}$ & $\begin{array}{l}\vec{\alpha} \\
0 \\
0 \\
0\end{array}$ & $\begin{array}{l}0 \\
\text { : } \\
0 \\
0\end{array}$ & $\begin{array}{l}\text { 莺 } \\
0 \\
0\end{array}$ & $\begin{array}{l}\overrightarrow{0} \\
\stackrel{\circ}{0} \\
\stackrel{0}{0}\end{array}$ & 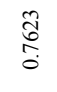 & $\underset{\overline{\vec{n}}}{\bar{n}}$ & 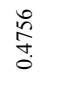 & $\begin{array}{l}\text { 敬 } \\
0\end{array}$ & $\begin{array}{l}\overrightarrow{0} \\
\stackrel{0}{0} \\
\stackrel{0}{0}\end{array}$ & $\begin{array}{l}\text { oे } \\
\hat{b} \\
0\end{array}$ & $\begin{array}{l}\text { 总 } \\
\stackrel{0}{0}\end{array}$ & $\stackrel{0}{\circ}$ & $\begin{array}{l}\vec{\infty} \\
\stackrel{0}{0} \\
0 \\
0\end{array}$ & & & & \\
\hline $\begin{array}{l}0 \\
\\
\end{array}$ & 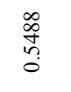 & $\begin{array}{l}\frac{1}{\infty} \\
\substack{\infty \\
0 \\
0}\end{array}$ & $\begin{array}{l}0 \\
\text { : } \\
\text { n. } \\
0\end{array}$ & $\begin{array}{l}\infty \\
\substack{\infty \\
\vdots \\
0 \\
0 \\
0}\end{array}$ & $\begin{array}{l}\text { 索 } \\
0\end{array}$ & 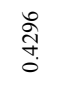 & $\begin{array}{l}\hat{f} \\
\text { fo } \\
0\end{array}$ & $\begin{array}{l}\underset{\Delta}{d} \\
\text { d. } \\
0\end{array}$ & 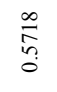 & $\begin{array}{l}\stackrel{\infty}{\circ} \\
\stackrel{\alpha}{\infty} \\
\infty\end{array}$ & 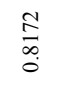 & 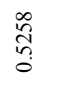 & $\begin{array}{l}n \\
\infty \\
0 \\
0 \\
0 \\
0\end{array}$ & $\begin{array}{l}\text { ô: } \\
\text { s. } \\
0\end{array}$ & $\begin{array}{l}\hat{\hat{b}} \\
\text { on } \\
0\end{array}$ & 定 & $\begin{array}{l}\text { ते } \\
\text { ه. } \\
0\end{array}$ & 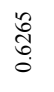 & 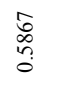 & $\begin{array}{l}\text { fे } \\
\text { f. } \\
\text { के }\end{array}$ & & & \\
\hline 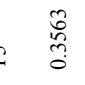 & 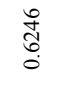 & $\begin{array}{l}\tilde{r} \\
\text { os } \\
\text { o. }\end{array}$ & \begin{tabular}{l}
8 \\
\multirow{o}{0}{} \\
\multirow{0}{0}{}
\end{tabular} & 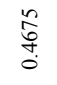 & 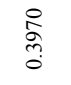 & $\begin{array}{l}\text { 尺े } \\
\text { ఫे }\end{array}$ & 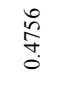 & $\begin{array}{l}\stackrel{+}{\hat{d}} \\
\text { d. }\end{array}$ & 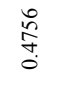 & 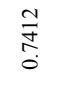 & 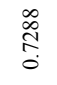 & 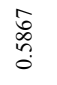 & 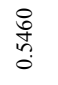 & 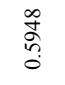 & $\begin{array}{l}\stackrel{8}{8} \\
\stackrel{0}{0}\end{array}$ & 总 & 命 & - & $\begin{array}{l}\infty \\
\stackrel{\infty}{\circ} \\
\text { oे } \\
0\end{array}$ & 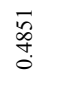 & 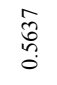 & & \\
\hline$\underset{\substack{\infty \\
\infty \\
\infty}}{\infty}$ & $\begin{array}{l}\text { Oे } \\
\text { b. } \\
0\end{array}$ & $\begin{array}{l}8 \\
0 \\
0 \\
0 \\
0\end{array}$ & 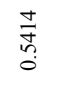 & $\begin{array}{l}\text { 志 } \\
\stackrel{0}{0}\end{array}$ & 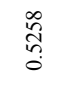 & $\begin{array}{l}\bar{o} \\
\text { ôt } \\
\text { on }\end{array}$ & 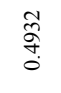 & $\begin{array}{l}\stackrel{+}{0} \\
0 \\
0 \\
0\end{array}$ & $\begin{array}{l}\text { 劣 } \\
\stackrel{0}{0} \\
0\end{array}$ & 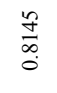 & 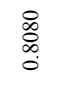 & 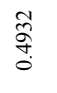 & $\begin{array}{l}\text { 迥 } \\
\text { ơ } \\
\text { ơ }\end{array}$ & $\begin{array}{l}\bar{\infty} \\
\stackrel{\infty}{0} \\
\stackrel{0}{0}\end{array}$ & $\stackrel{\substack{\infty \\
\stackrel{\infty}{0}}}{\stackrel{0}{0}}$ & $\begin{array}{l}\text { : } \\
\text { : } \\
\text { Oे }\end{array}$ & $\begin{array}{l}\stackrel{0}{\circ} \\
\stackrel{\infty}{0} \\
\stackrel{0}{0}\end{array}$ & 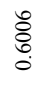 & $\begin{array}{l}\vec{\infty} \\
0 \\
0 \\
0 \\
0\end{array}$ & $\begin{array}{c}\frac{9}{9} \\
\substack{3 \\
0}\end{array}$ & $\overrightarrow{\bar{n}}$ & 寺 & \\
\hline$\frac{g}{0}$ & 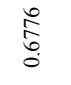 & $\begin{array}{l}\hat{F} \\
\stackrel{f}{f} \\
0\end{array}$ & 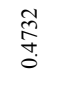 & $\begin{array}{l}\vec{E} \\
\stackrel{0}{0} \\
0\end{array}$ & $\begin{array}{l}\frac{\infty}{0} \\
0 \\
0\end{array}$ & 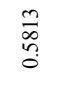 & $\begin{array}{l}\widehat{\widehat{d}} \\
0 \\
0\end{array}$ & 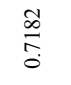 & $\begin{array}{l}m \\
\infty \\
\infty \\
0 \\
0\end{array}$ & $\frac{\hat{f}}{\vec{a}}$ & 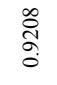 & $\begin{array}{l}\text { त్త్రి } \\
\stackrel{0}{\circ}\end{array}$ & $\begin{array}{l}\stackrel{n}{a} \\
\text { on } \\
o \\
0\end{array}$ & $\begin{array}{l}\text { त् } \\
0 \\
0\end{array}$ & 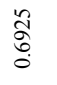 & $\begin{array}{l}\text { त్ } \\
\stackrel{0}{0} \\
0\end{array}$ & $\begin{array}{l}\text { Oे } \\
\text { Oे } \\
\text { o. }\end{array}$ & $\begin{array}{l}\vec{D} \\
\stackrel{\infty}{o} \\
\stackrel{0}{0}\end{array}$ & 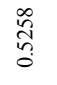 & $\begin{array}{l}n \\
0 \\
0 \\
o n \\
o\end{array}$ & $\begin{array}{l}\text { 今. } \\
\hat{0} \\
0\end{array}$ & 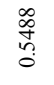 & in \\
\hline $\begin{array}{l}\text { ồ: } \\
\text { o. }\end{array}$ & $\begin{array}{l}\stackrel{a}{\circ} \\
\stackrel{0}{0}\end{array}$ & $\stackrel{\circ}{\stackrel{m}{0}}$ & 棠 & $\frac{8}{n}$ & 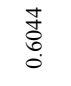 & $\begin{array}{l}\stackrel{0}{n} \\
\text { in } \\
0\end{array}$ & 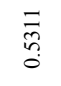 & $\begin{array}{l}\stackrel{0}{0} \\
0 \\
0 \\
0\end{array}$ & $\begin{array}{l}\hat{\hat{6}} \\
\text { ung } \\
0\end{array}$ & $\begin{array}{l}\stackrel{n}{2} \\
\infty \\
0 \\
0\end{array}$ & 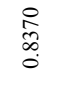 & $\begin{array}{l}\hat{0} \\
\text { o. } \\
n_{0}^{\prime}\end{array}$ & $\begin{array}{l}\text { 京 } \\
\text { in } \\
0\end{array}$ & $\begin{array}{l}0 \\
\vdots \\
\vdots \\
0 \\
0\end{array}$ & $\begin{array}{l}\text { 志 } \\
\stackrel{0}{0} \\
0\end{array}$ & 卓 & $\begin{array}{l}\text { ले } \\
\text { a. } \\
0\end{array}$ & 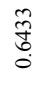 & 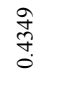 & $\begin{array}{l}\text { 总 } \\
\text { o. }\end{array}$ & 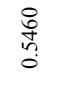 & 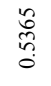 & \\
\hline
\end{tabular}




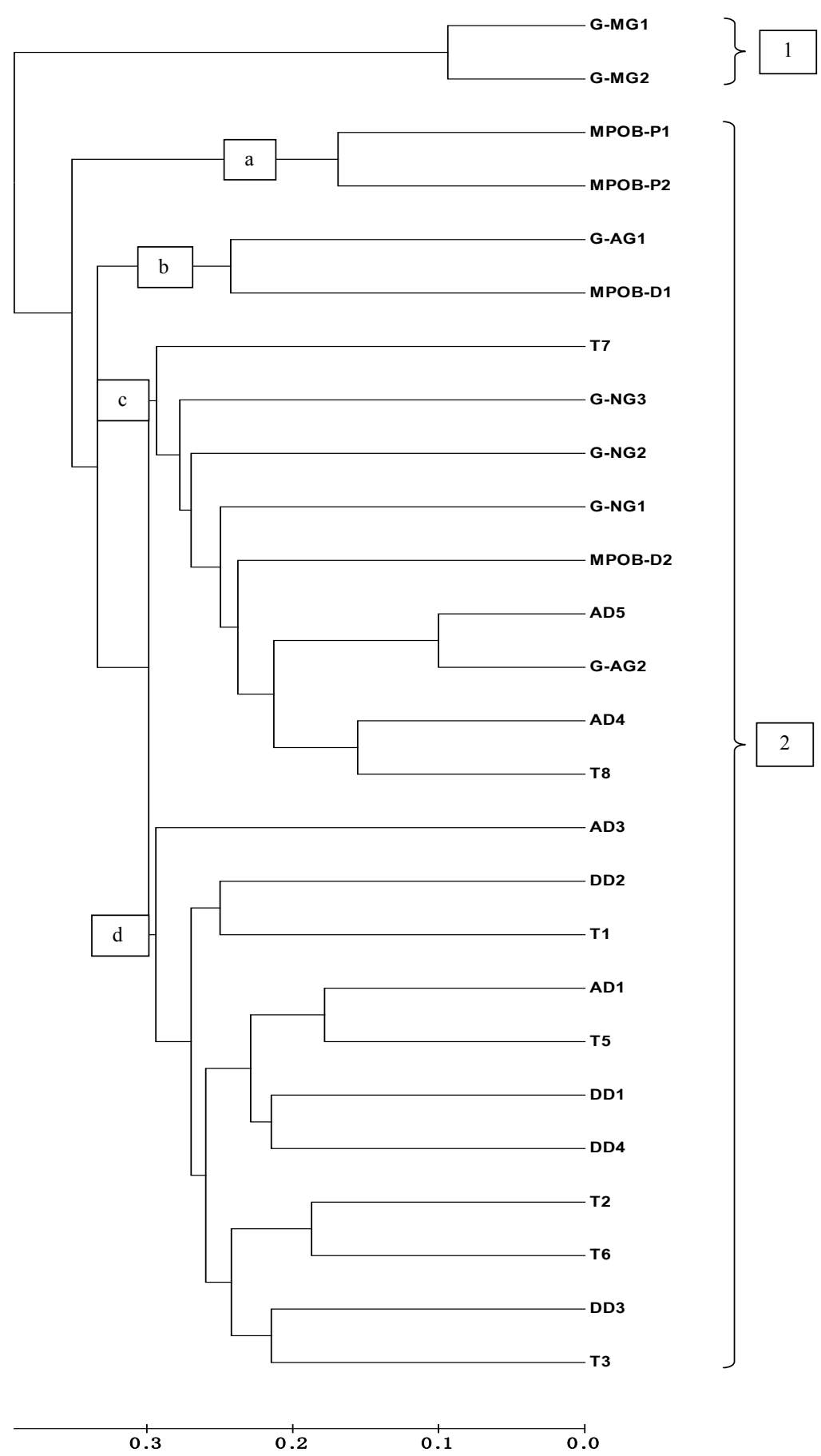

Figure 3. Dendrogram of breeding and germplasm genotypes constructed by UPGMA cluster analysis based on Rogers' pair-wise genetic distance

The PCoA assembled NIFOR and MPOB's breeding and germplasm genotypes into three clusters. Madagascarderived MPOB's germplasm genotypes formed a separate cluster. MPOB germplasm accessions from Nigeria (G-NG) and those from Angola (G-AG) were grouped with the NIFOR breeding parents in another cluster. A last cluster of four genotypes grouped two MPOB's Deli dura and two MPOB's pisifera (Figure 4). 


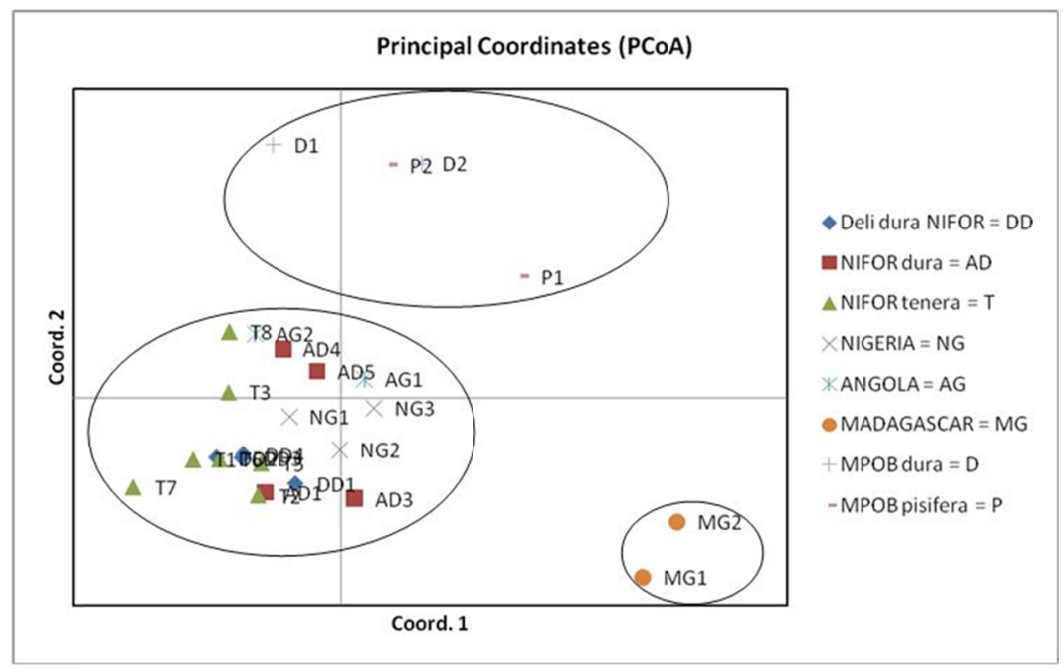

Figure 4. Principal coordinate analysis based on dissimilarity matrix using 9 SSR markers

\section{Discussion}

\subsection{Allelic Diversity}

Both allelic frequencies and number of alleles varied among and within the different oil palm groupings examined. Private alleles are valuable because they indicate the presence of novel genetic variation. Besides, it appears that higher percentages of specific alleles are a characteristic of Nigeria oil palm. A high number of private alleles were observed among the Nigeria accessions, NIFOR dura and tenera parents when compared to the Deli dura NIFOR parents and MPOB advanced dura and pisifera lines. Nigeria is the centre of distribution of oil palm, the presence of many private alleles may suggest that Nigeria is the centre of genetic diversity of the species. However, the method of seed selection/exchange practiced by the grove owners, given their preference for high mesocarp to fruit and oil to bunch ratio could probably explain the occurrence of private alleles in the Nigeria oil palm. Zeng et al. (2004) considered unique alleles (or alleles not detected in commercial cultivars) in breeding lines and land races of rice were related to their adaptation to saline soils. It is therefore possible that the adaptation of the palms to the relatively impoverished soil characterizing the main oil palm belt of Nigeria could shed some light on the presence of private alleles. For instance, the Umuabi location is derived savannah ecology in the north eastern limit of the oil palm belt of Nigeria. It is generally regarded as marginal for oil palm production with lower $(<2000 \mathrm{~mm})$ rainfall distribution per annum. This drought stressed environment can lead to development of gene rearrangements that will induce adaptation processes at the molecular-genetic level of the oil palm. The slow annual growth rate (short-stem) of the palms from this location could be considered a form of adaptation to the marginal environment of the area. Similar instances were revealed using isozymes (Hayati et al., 2004) and microsatellite markers (Bakoumé et al., 2015), which was attributed to adaptive genetic variants.

\subsection{Polymorphism Information Content (PIC)}

The high average PIC value of 0.7325 shows the robustness of SSRs in detecting polymorphism within the different oil palm sources evaluated. It is also a further confirmation of the high polymorphism of the selected SSR markers employed for this study (Billotte et al., 2005; Singh et al., 2008). The 16 microsatellite markers initially screened with 26 oil palm genotypes were selected for their high polymorphism and represented the 16 linkage groups of the entire oil palm genome. The high average PIC value is an indication of a reliable estimate of genetic diversity parameters considering that only nine SSRs covering to an extent $56.25 \%$ of the oil palm genome was eventually used for analysis.

\subsection{Mean number of Amplified Alleles $\left(A_{o}\right)$ and Effective Number of Alleles $\left(A_{e}\right)$}

The total number of amplified alleles (80) as well as the average number of amplified alleles per marker (8.89) was relatively lower compared to previous results. Cochard et al. (2009) reported a total of 202 and an average of 14.4 amplified alleles per locus among 318 oil palm genotypes from eight countries involving 27 origins using 14 SSR markers. Recently, Bakoumé et al. (2015) reported an average of 13.1 amplified alleles per locus among 49 oil palm populations representing ten African countries, three breeding materials, and one semi-wild material 
using 16 SSRs. These differences could be ascribed to disparity in the materials evaluated. The number of samples used in the current study was low. It is related to the limited number of elite palms which have performed well in the progeny tests leading to their selection for seed production and for the next breeding programmes. The number of alleles per locus also could have depended on the SSR markers used. In fact, Cochard et al. (2009) and Bakoumé et al. (2015) used comparable sets of SSR markers different from the one employed in the present study.

The allelic diversity of the 8 sources of oil palm materials was assessed independently. The mean number of alleles $\left(A_{o}=2.958\right)$ and effective number of alleles for the respective oil palm groupings $\left(A_{e}=2.445\right)$ was relatively higher than the values $\left(A_{0} \leq 2.0\right)$ reported using different marker techniques such as RFLP (Maizura et al., 2006) and isozymes (Hayati et al., 2004; Purba et al., 2000). SSRs have revealed more alleles than other marker techniques. The effective number of alleles $\left(A_{e}=2.445\right)$ is comparable to the value $\left(A_{e}=2.68\right)$ reported by Taeprayoon et al. (2015) for oil palm breeding populations obtained from three Thai breeding companies. Earlier studies using microsatellite markers in oil palm and in different plant species verified the presence of variability in number of detected alleles among genotypes. According to Bakoumé et al. (2015), this variation could be associated with the number of accessions sampled and origin of the samples from each population.

The high allelic variability observed in Nigeria and Angola oil palm germplasm collections (evidenced by high values of $\mathrm{A}_{0}$ ) were exploited in MPOB improvement programme to diversify their planting materials. The MPOBs dwarf and high yielding planting materials (PS1), high iodine content and high yielding planting materials (PS2), and high kernel content planting materials (PS3) were developed from selected palms from Nigeria (Rajanaidu, 1994a, 1994b, 1996). The Angola palms with large fruit dura were selected as PS6 planting material (Kushairi et al., 2003). It would not be surprising if some of their alleles may be related to genes controlling the agronomic traits for which they were selected.

\subsection{Observed Heterozygosity $\left(H_{o}\right)$ and Expected Heterozygosity $\left(H_{e}\right)$}

The mean $\mathrm{H}_{\mathrm{o}}$ and $\mathrm{H}_{\mathrm{e}}$ values in this study was 0.6296 and 0.7616 , respectively, higher compared to those reported by Ting et al. (2010) (0.400 and 0.437, respectively) using 15 SSR markers and Bakoumé et al. (2015) (0.460 and 0.644 , respectively) using 16 SSR markers. These high mean values of $\mathrm{H}_{\mathrm{o}}$ and $\mathrm{H}_{\mathrm{e}}$ depicted the high genetic variability in the oil palm samples evaluated in this study notwithstanding that the materials have undergone some selection and breeding activities. In fact, the principle in oil palm breeding is to exploit complementarities of different agronomic traits while preventing inbreeding effect that depresses yields. Open pollination that prevails in the natural oil palm groves whereby an oil palm tree receives pollens from many donor trees contributes to increasing allelic diversity. Results of the present study $\left(\mathrm{H}_{\mathrm{e}}=0.347\right)$ and the previous study by Ting et al. $\left(2010 ; \mathrm{H}_{\mathrm{e}}=0.340\right)$ revealed the presence of low genetic variation among MPOB Deli dura. The Deli dura has undergone several cycles of selection compared to NIFOR Deli dura. The absence of unique alleles buttresses the narrow genetic base of Deli dura, contrary to the relatively broad genetic base of the NIFOR oil palm breeding materials.

\subsection{Genetic Differentiation and Relatedness among NIFOR and MPOB Breeding and Germplasm Materials}

The AMOVA showed significant and large value of genetic differentiation $\left(\mathrm{F}_{\mathrm{ST}}=0.177, \mathrm{P}=0.001\right)$ and indicating that the total genetic diversity observed was due to genetic differentiation within the sources of parental materials like in most perennial out-breeding species which maintain most of their variation within populations (Hamrick et al., 1992). Genetic distance is a measure of the genetic divergence between species or between populations within a species. The average genetic distances among the 26 different oil palm sources was high $\left(D_{R}=0.6150\right)$, indicating a moderate degree of genetic dissimilarity among the individual palms. This can be exploited for designing crosses aimed at maximizing the genetic gains of heterosis in oil palm improvement programme. However, the low genetic distance $\left(D_{R}=0.2000\right)$ observed between NIFOR dura AD5 from Aba and Angola accession G-AG2 maintained at MPOB germplasm, may indicate that the oil palms from the two geographical zones might have been derived from similar genetic background. Similar observation was reported by Bakoumé (2006). The dendogram showed total divergence of oil palm material from Madagascar from all other materials evaluated in this study. Indeed, oil palms from Madagascar Island have been reported to be distinct from oil palm of the African oil palm belt for many morpho-physiological characters. In fact, they have a short trunk, high iodine value, and high linoleic acid (C18:2) oils compared to mainland palms (Hartley, 1988; Rajanaidu et al., 2000). The grouping of Nigeria accessions from MPOB and some of the NIFOR breeding materials in the same cluster confirmed their common origin. Similarly, the NIFOR tenera T8 (a descendant of Ufuma x Angola) and Angola accession G-AG2 maintained at MPOB germplasm which share a common genetic Angolan background were grouped in the same cluster. It was of interest to note that cluster analysis did not 
entirely group genotypes according to their provenances. This result is congruent with Bakoumé et al. (2015) and Cochard et al. (2009) who found that accessions from Nigeria, Cameroon, and Angola were grouped in the same cluster. Furthermore, it has also been suggested that the possible origin of Deli materials is in a region covering Nigeria, Cameroon, Zaire, and Angola (Bakoumé et al., 2015). The genetic divergence and clustering of genotypes by PcoA should be a good asset for the exploitation of the heterosis in the intra-group and inter-group crosses of the reciprocal recurrent selection. The differences observed between the MPOB advanced breeding lines and the NIFOR breeding materials in the PCoA was probably associated with loss of alleles by MPOB's materials due to several selection cycles that could have led to a loss of alleles not related to traits of agronomic interest. Furthermore, different breeding objectives might have resulted in the fixation of different alleles.

\section{Conclusion}

The present study gives an insight on the genetic diversity of NIFOR oil palm parents with reference to MPOB's advanced breeding lines and some of its African oil palm germplasm materials using 9 SSR markers. The variable levels of genetic differentiation among and within the provenances provide an opportunity for selection of diverse parents to be used in parental crosses. The relative high genetic diversity and the unique features (high bunch production and low stem increment) of the Nigeria oil palm germplasm collections examined in this study highlights the potential for further improvement on plant architecture and plant yields. Exchange of oil palm genetic resources with MPOB can be envisaging on both agronomic performance and genetic bases.

\section{Acknowledgements}

The authors thank the Director-General of MPOB, for providing laboratory facilities at the Advanced Biotechnology and Breeding Centre (ABBC) for microsatellite genetic analyses. We also thank Dr. Ravigadevi Sambanthamurthi for her logistic support, Ms. Rahimah Abd Rahman for her assistance in the microsatellite assays, Mdm. Ting Ngoot Chin for her technical assistance during capillary electrophoresis, and Dr. Maizura Ithnin for her assistance in statistical analysis. The assistance of Mdm. Maryann Okoye, Ms. Collette Okoye, Messrs. Innocent Ani, Godfrey Akpan, and Godspower Oviawe in field work is also acknowledged.

\section{References}

Anderson, J. A., Churchill, G. A., Autrique, J. E., Tanksley, S. D., \& Sorrells, M. E. (1993). Optimizing Parental Selection for Genetic Linkage Maps. Genome, 36, 181-186. http://dx.doi.org/10.1139/g93-024

Arias, D., Montoya, C., Rey, L., \& Romero, H. (2012). Genetic Similarity among Commercial Oil Palm Materials Based on Microsatellite Markers. Agronomía Colombiana, 30(2), 188-195.

Ataga, C. D. (1988). Variation, intercharacter relationships and stability in some oil palm (Genus, Elaeis) populations (Unpublished doctoral thesis, University of Ibadan, Nigeria).

Bakoumé, C. (2006). Genetic diversity of natural oil palm (Elaeis guineensis Jacq.) populations using microsatellite markers (Unpublished doctoral thesis, Universiti Kebangsaan, Malaysia).

Bakoumé, C., Aziah, M. Y., Praveena, T., Teh, C. K., Suzaini, Y., Hamidah, M., ... Harikrishna, K. (2011). DNA Sequence-Based Markers for Verification of Ramet-to-Ortet Relationship in Oil Palm (Elaeis guineensis Jacq.). American Journal of Plant Sciences, 2, 539-548. http://dx.doi.org/10.4236/ajps.2011.24064

Bakoumé, C., Wickneswari, R., Rajanaidu, N., Kushairi, A., Amblard, P., \& Billotte, N. (2007). Allelic Diversity of Natural Oil Palm (Elaeis guineensis Jacq.) Populations Detected by Microsatellite Markers: Implications for conservation. Plant Genetic Resources C\&U, 5(2), 104-107. http://dx.doi.org/10.1017/S1479262107710870

Bakoumé, C., Wickneswari, R., Siju, S., Rajanaidu, N., Kushairi, A., \& Billotte, N. (2015). Genetic Diversity of the World's Largest Oil Palm (Elaeis guineensis Jacq.) Field Genebank Accessions Using Microsatellite Markers. Genetic Resources and Crop Evolution, 62, 349-360. http://dx.doi.org/10.1007/s10722-014-0156-8.

Basri Wahid, M., Abdullah, S. N. A., \& Henson, I. (2005). Oil Palm-Achievements and Potential. Plant Production Science, 8, 288-297. http://dx.doi.org/10.1626/pps.8.288

Billotte, N., Marseillac, N., Risterucci, A., Adon, B., Brottier, P., Baurens, F., ... Charrier, A. (2005). Microsatellite-Based High Density Linkage Map in Oil Palm (Elaeis guineensis Jacq.). Theoretical and Applied Genetics, 110, 754-765. http://dx.doi.org/10.1007/s00122-004-1901-8

Billotte, N., Rusterucci, A., Barcelos, E., Noyer, J., Amblard, P., \& Baurens, F. (2001). Development, Characterization, and Across-Taxa Utility of Oil Palm (Elaeis guineensis Jacq.) Microsatellite Markers. 
Genome, 44(3), 413-425.

Botstein, D., White, R. L., Skolnick, M., \& Davis, R. W. (1980). Construction of a Genetic Linkage Map in Man Using Restriction Fragment Length Polymorphisms. American Journal of Human Genetics, 32, 314-331.

Brumlop, S., \& Finckh, M. R. (2010). Applications and Potentials of Marker Assisted Selection (MAS) in Plant Breeding. Bundesamt für Naturschutz (BfN) Federal Agency for Nature Conservation Konstantinstrasse 110, 53179 Bonn, Germany. Retrieved from http://www.bfn.de/0502_skripten.html

Cochard, B., Adon, B., Rekima, S., Billotte, N., Desmier, R., Koutou, A., ... Noyer, J. L. (2009). Geographic and Genetic Structure of African Oil Palm Diversity Suggests New Approaches to Breeding. Tree Genetics and Genomes, 5(3), 493-504. http://dx.doi.org/10.1007/s11295-009-0203-3

Corley, R. H. V., \& Tinker, P. B. (2003). Selection and Breeding. The oil palm (4th ed.). Blackwell Science. http://dx.doi.org/10.1002/9780470750971.ch5

Crow, J. F., \& Kimura, M. (1970). An introduction to to population genetic theory. Harper and Row, New York.

Doyle, J. J., \& Doyle, J. L. (1990). Isolation of Plant DNA from Fresh Tissue. Focus, 12, 13-15.

Excoffier, L., Smouse, P. E., \& Quattro, J. M. (1992). Analysis of Molecular Variance Inferred from Metric Distances among DNA Haplotypes: Application to human mitochondrial DNA restriction data. Genetics, $131,479-491$.

Feng, S. P., Li, W. G., Huang, H. S., Wang, J. Y., \& Wu, Y. T. (2009). Development, Characterization and Cross-species/genera Transferability of EST-SSR Markers for Rubber Tree. Molecular Breeding, 23, 85-97. http://dx.doi.org/10.1007/s11032-008-9216-0

Gupta, P. K., Varshney, R. K., Sharma, P. C., \& Ramesh, B. (1999). Molecular Markers and their Applications in Wheat Breeding. Plant Breeding, 118, 369-390. http://dx.doi.org/10.1046/j.1439-0523.1999.00401.x

Hama-Ali, E. O., Alwee, S. S. R. S., Tan, G. S., Panandam, J. M., Ling, H. C., Namasivayam, P., \& Peng, H. B. (2014). Illegitimacy and Sibship Assignments in Oil Palm (Elaeis guineensis Jacq.) Half-sib Families using Single Locus DNA Microsatellite Markers. Molecular Biology Report. http://dx.doi.org/10.1007/s11033-014-3829-7

Hamrick, J. L., Godt, M. J. W., \& Sherman-Broyles, S. L. (1992). Factors Influencing Levels of Genetic Diversity in Woody Plant Species. New Forests, 6, 95-124. http://dx.doi.org/10.1007/BF00120641

Hartley, C. W. S. (1988). The Oil Palm (Elaeis guineensis Jacq.). New York: Longman Scientific and Technical Publication.

Hayati, A., Wickneswari, R., Maizura, I., \& Rajanaidu, N. (2004). Genetic Diversity of Oil Palm (Elaeis guineensis Jacq.) Germplasm Collections From Africa: Implications for improvement and conservation of genetic resources. Theoretical and Applied Genetics, 108, 1274-1284. http://dx.doi.org/10.1007/s00122-003-1545-0

Kushairi, A., Rajanaidu, N., Mohd Din, A., Isa, Z. A., Noh, A., \& Junaidah, J. (2003). Palm Series 6 (PS6)-Breeding populations selected for large fruit duras. MPOB Information Series 184. MPOB, Bangi, Selangor.

Liu, K., \& Muse, S. V. (2005). PowerMarker: An integrated analysis environment for genetic marker analysis. Bioinformatics, 21, 2128-2129. http://dx.doi.org/10.1093/bioinformatics/bti282

Low, E. T. L., Halimah, A., Boon, S. H., Elyana, M. S., Tan, C. Y., Ooi, L. C. L., ... Singh, R. (2008). Oil Palm (Elaeis guineensis Jacq.) Tissue Culture ESTs: Identifying genes associated with callogenesis and embryogenesis. BMC Plant Biology, 8, 62. http://dx.doi.org/10.1186/1471-2229-8-62

Maizura, I., Rajanaidu, N., Zakri, A., \& Cheah, S. (2006). Assessment of Genetic Diversity in Oil Palm (Elaeis guineensis Jacq) Using Restriction Fragment Length Polymorphism (RFLP). Genetic Resource and Crop Evolution, 53, 187-195. http://dx.doi.org/10.1007/s10722-004-4004-0

Marshall, D. R., \& Brown, A. H. D. (1975). Optimum sampling strategy in genetic conservation. In O. H. Frankel \& J. G. Hawkes (Eds.), Crop genetic resources for today and tomorrow (pp. 53-80). Cambridge University Press, London.

McCouch, S. R., Teytelman, L., Xu, Y., Lobos, K. B., Clare, K., Walton, M., et al. (2002). Development and Mapping of 2240 New SSR Markers for Rice (Oryza sativa L.). DNA Research, 9, $257-279$. http://dx.doi.org/10.1093/dnares/9.6.257 
Mohammadi, S. A., \& Prasanna, B. M. (2003). Analysis of Genetic Diversity in Crop Plants salient statistical tools and considerations. Review and Interpretation. Crop Science, 43, 1235-1248. http://dx.doi.org/10.2135/cropsci2003.1235

Mohan, M., Nair, S., Bhagwat, A., Krishna, T. G., Yano, M., Bhatia, C. R., \& Sasaki, T. (1997). Genome Mapping, Molecular Markers and Marker-Assisted Selection in Crop Plants. Molecular Breeding, 3, 87-103. http://dx.doi.org/10.1023/A:1009651919792

Mohd Basri, W., Siti Nor, A. A., \& Henson, I. E. (2005). Oil Palm-Achievements and potential. Oil Palm Bulletin, 50, 1-13. http://dx.doi.org/10.1626/pps.8.288

Nei, M. (1972). Genetic Distance between Populations. American Naturalist, 106, $283-292$. http://dx.doi.org/10.1086/282771

Nigerian Institute for Oil Palm Research. (1988). NIFOR/MARDI germplasm collections and evaluation. NIFOR Ann. Report, 25, 56-60.

Noorhariza, M. Z., Ismanizan, I., Rozana, R., Ting, N. C., \& Singh, R. (2010). Development and Characterization of Elaeis oleifera Microsatellite Markers. Sains Malaysia, 39(6), 909-912.

Norziha, A., Rafii, M., Maizura, I., \& Ghizanm, S. (2008). Genetic Variation among Oil Palm Parent Genotypes and their Progenies based on Microsatellite Markers. Journal of Oil Palm Research, 20, 533-541.

Obasola, C. O., Arasu, N. T., \& Rajanaidu, N. (1983). Collection of Oil Palm Genetic Material in Nigeria. I. Method of collection. MARDI Report No. 80.

Oil World. (2014). Oil World Annual. ISTA Mielke, Hamburg.

Okoye, M. N. (2008). Stability and Genetic Variability of Bunch Yield Components of NIFOR Second Cycle Oil Palm Hybrids (M.Sc. Thesis, University of Nigeria Nsukka).

Okwuagwu, C. O. (1986). The Genetic Basis of the NIFOR Oil Palm Breeding Programme. Proceedings of International Workshop on Oil Palm Germplasm and Utilization (No. 10, pp. 228-237). Palm Oil Research. Institute, Malaysia.

Okwuagwu, C. O., Ataga, C. D., Okolo, E. C., Ikuenobe, C. E., \& Ugbah, M. M. (2005). The production of NIFOR Elite-tenera Hybrid Planting Material - The NIFOR EWS. Technical Report, Nigerian Institute for Oil Palm Research (NIFOR), Benin City, Nigeria.

Okwuagwu, C. O., Okoye, M. N., Okolo, E. C., Ataga, C. D., \& Uguru, M. I. (2008). Genetic Variability of Fresh Fruit Bunch Yield in Deli/dura x tenera Breeding Populations of Oil Palm (Elaeis guineensis Jacq.) in Nigeria. Journal of Tropical Agriculture, 46(1-2), 40-45.

Peakall, R., \& Smouse, P. (2006). GenAlEx version 6.0: Genetic Analysis in Excel. Population Genetic Software for Teaching and Research. Molecular Ecology, 6, 288-295. http://dx.doi.org/10.1111/j.1471-8286.2005.01155.x

Peakall, R., Gilmore, S., Keys, W., Morgante, M., \& Rafalski, A. (1998). Cross-species Amplification of Soybean (Glycine Max) Simple Sequence Repeats (SSRs) within the Genus and other Legume Genera: Implications for the transfer ability of SSRs in plants. Molecular Biology and Evolution, 15, 1275-1287. http://dx.doi.org/10.1093/oxfordjournals.molbev.a025856

Perrier, X., \& Jacquemoud-Collet, J. P. (2006). DARwin software. Retrieved from http://darwin.cirad.fr/darwin

Philips, R. L., \& Vasil, I. K. (1994). Introduction: Molecular maps of major crop species. In R. L. Philips \& I. K. Vasil (Eds.), DNA-Based Markers in Plants (pp. 142-143). Kluwer Academic Publishers. http://dx.doi.org/10.1007/978-94-011-1104-1_7

Powell, W., Morgante, M., Andre, C., Hanafey, M., Vogel, J., Tingey, S., \& Rafalski, A. (1996). The Comparison of RFLP, RAPD, AFLP and SSR (microsatellite) Markers for Germplasm Analysis. Molecular Breeding, 2, 225-238. http://dx.doi.org/10.1007/BF00564200

Rajanaidu, N. (1994a). MPOB Series No. 1-MPOB elite oil palm. MPOB Information Series No. 15. MPOB, Bangi, Selangor.

Rajanaidu, N. (1994b). MPOB Series No. 2-MPOB elite oil palm. MPOB Information Series No. 16. MPOB, Bangi, Selangor.

Rajanaidu, N. (1996). PORIM elite oil palm Series 3 (mother palm) - High kernel. PORIM Information Series No. 41. MPOB, Bangi, Selangor. 
Rajanaidu, N., Kushairi, A., Rafii, M., Din, M., Maizura, I., \& Jalani, B. S. (2000). Oil Palm Breeding and Genetic Resources. In Y. Basiron, B. S. Jalani, \& K. W. Chan (Eds.), Advances in Oil Palm Research (pp. 171-227). Malaysian Palm Oil Board, Kuala Lumpur.

Rajinder, S., Jayanthi, N., Soon-Guan, T., Jothi Malar, P., \& Suan-Choo, C. (2007). Development of Simple Sequence Repeat (SSR) Markers for Oil Palm and their Application in Genetic Mapping and Fingerprinting of Tissue Culture Clones. Asian Pacific Journal of Molecular Biotechnology, 15(3), 121-131.

Rogers, J. S. (1972). Measures of Genetic Similarity and Genetic Distance. Studies in Genetics VII (pp. 145-153). University of Texas Publication 7213, Austin, Texas.

Rosenquist, E. A. (1986). The genetic base of oil palm breeding populations. Proceedings of the International Workshop on Oil Palm Germplasm and Utilisation (pp. 27-56). Palm Oil Research Institute of Malaysia, Kuala Lumpur, Malaysia.

Saghai-Maroof, M. A., Biyashev, R. M., Yang, G. P., Zhang, Q., \& Allard, R. W. (1994). Extraordinarily polymorphic Microsatellite DNA in Barley: Species diversity, chromosomal locations, and population dynamics. Proceedings of National Academy of Science (USA), 91, 5466-5470. http://dx.doi.org/10.1073/pnas.91.12.5466

Shah, F. H., Rashid, O., Simons, A. J., \& Dunsdon, A. (1994). The Utility of RAPD Markers for the Determination of Genetic Variation in the Oil Palm (Elaeis guineensis). Theoretical and Applied Genetics, 89, 713-718. http://dx.doi.org/10.1007/BF00223710

Singh, R., \& Cheah, S. C. (2005). Potential Application of Marker Assisted Selection (MAS) in Oil Palm. Oil Palm Bulletin, 51, 1-9.

Singh, R., Noorhariza, M. Z., Ting, N. C., Rozana, R., Tan, S. G., Low, L. E. T., ... Cheah, S. C. (2008). Exploiting an Oil Palm EST Database for the Development of Gene-derived SSR Markers and their exploitation for Assessment of Genetic Diversity. Biologia, 63, 1-9. http://dx.doi.org/10.2478/s11756-008-0041-z

Sneath, P. H. A., \& Sokal, R. R. (1973). Numerical Taxonomy: The Principles and Practice of Numerical Classification. W. H. Freeman: San Francisco, CA, USA.

Sparnnaij, L. D. (1972). Reports on a visit to the Nigerian Institute for Oil Palm Research (p. 18).

Tamura, K., Dudley, J., Nei, M., \& Kumar, S. (2007). MEGA 4: Molecular Evolutionary Genetics Analysis (MEGA) software version 4.0. Molecular Biology and Evolution, 24, 1596-1599. http://dx.doi.org/10.1093/molbev/msm092

Thawaro, S., \& Te-Chato, S. (2010). Verification of Legitimate Tenera Oil Palm Hybrids Using SSR and Propagation of Hybrids by Somatic Embryogenesis. Songklanakarin Journal of Science and Technology, $32(1), 1-8$.

Ting, N. C., Jansen, J., Nagappan, J., Ishak, Z., Chin, C. W., Tan, S. G., ... Singh, R. (2013). Identification of QTLs Associated with Callogenesis and Embryogenesis in Oil Palm Using Genetic Linkage Maps $\begin{array}{lllllll}\text { Improved with SSR Markers. PLoS ONE, } & \text { 8(1), } & \text { 1-16. } & \text { e53076. }\end{array}$ http://dx.doi.org/10.1371/journal.pone.0053076

Ting, N. C., Noorhariza, M. Z., Rozana, R., Low, E. T., Ithnin, M., Cheah, S. C., ... Singh, R. (2010). SSR Mining in Oil Palm EST Database: Application in oil palm germplasm diversity studies. Journal of Genetics, 89, 135-145. http://dx.doi.org/10.1007/s12041-010-0053-7

West, M. J. (1976). The analysis of the bunch yield data of the NIFOR oil palm breeding programme and the choice of new parental material. A supplementary report of the ministry of Overseas Development on Research Project. R2354. Mimeo (p. 41).

Zane, L., Bargelloni, L., \& Patarnello, T. (2002). Strategies for microsatellite isolation: A review. Molecular Ecology, 11, 1-16. http://dx.doi.org/10.1046/j.0962-1083.2001.01418.x

Zeng, L., Kwon, T. R., Liu, X., et al. (2006). Genetic diversity analyzed by microsatellite markers among rice (Oryza sativa L.) genotypes with different adaptations to saline soils. Plant Science, 116, 1275-1285. 


\section{Copyrights}

Copyright for this article is retained by the author(s), with first publication rights granted to the journal.

This is an open-access article distributed under the terms and conditions of the Creative Commons Attribution license (http://creativecommons.org/licenses/by/3.0/). 